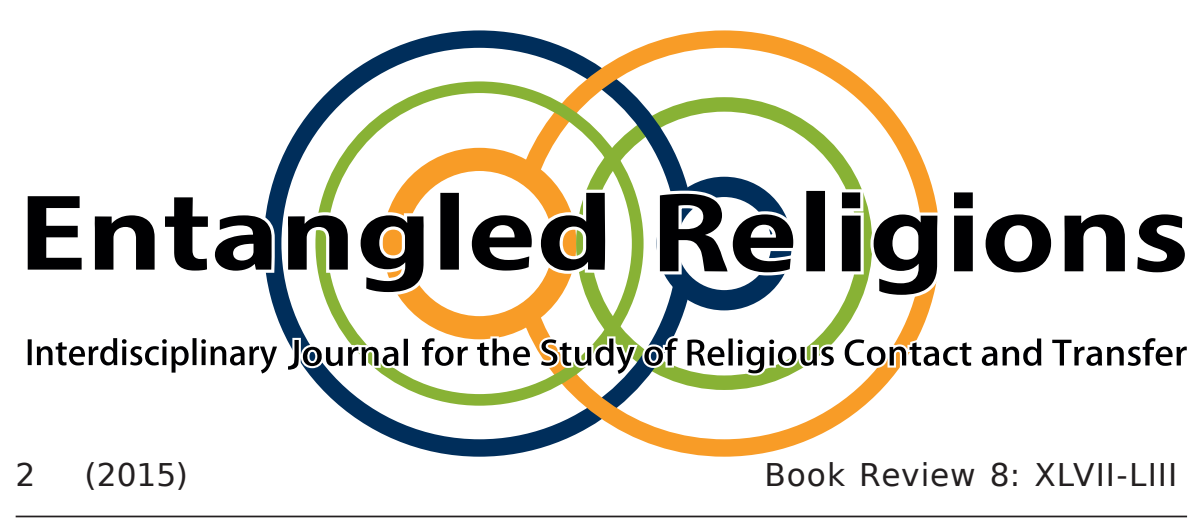

Understanding Muslim Chaplaincy

Farnham: Ashgate, 2013. 206 pages, paperback f19.99, ISBN 978-1409435938.

SOPHIE GILLIAT-RAY, MANSUR ALI \& STEPHEN PATTISON

(c) 2015 Ruhr-Universität Bochum ISSN 2363-6696
Entangled Religions 2 (2015) http://dx.doi.org./10.13154/er.v2.2015.XLVII-LIII

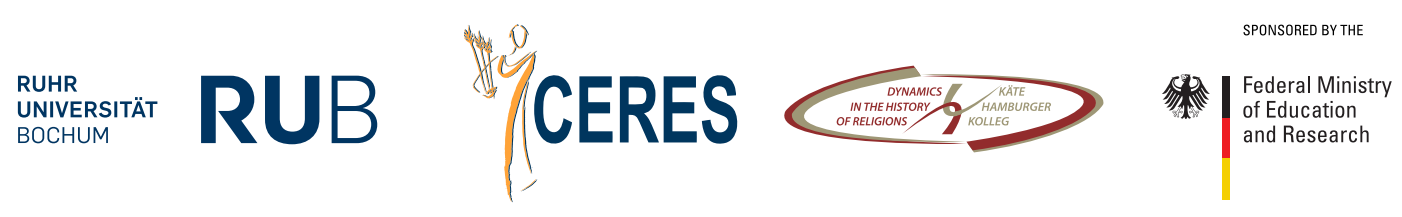




\title{
Understanding Muslim Chaplaincy
}

\author{
Farnham: Ashgate, 2013. 206 pages, \\ paperback f19.99, ISBN 978-1409435938.
}

SOPHIE GILLIAT-RAY, MANSUR ALI \& STEPHEN PATTISON

A new term is about to gain terrain in studies on Islam in Europe irrespective of differences between national regimes of religion: 'Muslim chaplaincy', 'Islamic pastoral care' or in its German version: 'islamische Seelsorge'. The research is of very recent date, the phenomenon itself is not much older.

Actually, the use of a classical Christian concept for Islam provokes irritation, hesitation, if not rejection. For example, it is hardly possible that a term like 'Islamic church' could make a career, although Muslim associations in Europe show many characteristics of a church organization - they strive for the status and privileges of Christian churches. But 'Islamic Church' is a term that will most likely meet with widespread rejection. Muslim chaplaincy, however, is going to become a profession with due practical relevance and institutional acceptance.

Studies on Muslim chaplaincy can make valuable contributions to the debate on 'Euro-Islam' by directing interest towards processes of institutionalization. Therefore, studying Muslim chaplaincy will help to raise awareness of a theoretical approach that attributes particular importance to the encounter of religions for their formations. Muslim Chaplaincy is a product of religions' encounter, as is evident already in the term itself.

The authors are well-experienced in their research field - both regarding academic skills, as well as practical knowledge. With this book they deliver rich empirical material on Muslim Chaplaincy in England and Wales based 
on extensive qualitative data. And they pave the way for further research that is also still at its very beginning in the German speaking world. The book is divided into 8 chapters and seeks to answer a range of practical questions like:

"who decides to become a Muslim chaplain, and why? What skills, training or experience do they bring to their role? Given that there is no formal institutionalised tradition of pastoral care in Islam, what do Muslim chaplains actually do?" (p. 12).

The individual chapters present a short history of Muslim chaplaincy in Britain, evolving from occasional 'visiting ministers' in hospitals and prisons into a durable profession explicitly called 'Muslim chaplain'; they further face the challenge of imbedding chaplaincy into Islamic tradition, followed by chapters outlining the profile of chaplaincy people, practices and politics of chaplaincy. These detailed descriptions are complemented by a comparison with the American case of Muslim chaplaincy. The book closes with a discussion of differences between Muslim and Christian chaplaincy.

The authors are, no doubt, aware of the difficulties which any adaptation of concepts from other traditions would cause. The challenge is that of making such new terms compatible with one's own tradition. This challenge poses itself both to the academics who conduct research on, as well as the practioners who choose, or are expected to operate under, this title. The institutional tradition of Islam does indeed not know the concept of pastoral care. Thus, researchers as well as Muslim chaplains in Europe have to proof its compatibility with Islam (Ch. 2). The authors are cautious enough not to simply assume a hidden concept of pastoral care in Islam, waiting to be discovered at the right moment. They rather decide to use "pastoral" more "broadly" (p. 25). 
That can be identified, as they claim, easily within Islam, too: “These [significant elements of belief and practice, L.T.] are fundamentally to do with helping people individually and corporately to grow and to flourish, and to resist and overcome diminishment and debilitation as they try to love God and humanity" (p. 25) It might be justly argued that the term 'pastoral' is overstretched. But this objection seems obsolete. Irrespective of whether it fits into the classical Islamic terminology or not, Muslim chaplaincy has got its own reality that has emerged from the interplay of diverse factors. This study does exactly what a scholarly work has to do: it describes this interplay.

Muslim chaplaincy arose from the initiative of few people (p. 165) who responded to the expectations of institutions such as prisons, hospitals, HM Courts, leisure attractions, airports, shopping centres etc. Muslim associations obviously do not seem to have been among the primary promoters. Impulses from non-religious environments have actually always been crucial for the formation of religious institutions. Thus, the National Health Service, for example, contributed heavily to the appointment of Muslim chaplains by helping to secure positions; the Markfield Institute of Higher Education provided training and accreditation by developing the "Certificate in Muslim Chaplaincy" (pp. 5-11). But such institutional input cannot alone ensure the formation of a sustainable socio-religious role. Chaplaincy has some benefits that make it attractive. To give some examples: For women, chaplaincy opens up career options which otherwise would not be available to them in the religious domain (p. 165). While many "men come into chaplaincy from a scholarly religious background", most female chaplains (...) have some form of prior experience (...) such as counselling, community work or a health care profession" (p. 93). But benefits of chaplaincy are not thoroughly genderized. As chaplain, the religious scholars work outside the mosque and experience being 
considered autonomous religious professionals; this "contrasts with the role of mosque-based imams, for example, who often have little autonomy" (p. 169).

The study provides us not only with empirical material about the practise of Muslim chaplaincy. In the conclusion, a comparison with Christian chaplaincy shows that the adaptation of a certain institution or role does not mean copying it into another tradition.

It is striking but not surprising that Muslim chaplaincy work is based to a huge degree upon liturgical activities. Connected to this is the observation that chaplaincy work seeks its addressee mostly in families while Christian pastoral care operates by individualizing its objects. ${ }^{1}$ Due to different settings of Christianity and Islam, the objects of their focuses differ, as well. Muslim chaplains pay much attention to law and legal interpretation of Islam, i.e. practical/correct behaviour; for Christian chaplains 'correct' practice is not that important (p. 169). And finally, all these differences refer to the question of whether there is a sending institution such as a church, or not. Eventually, because there is no Islamic church, an educational institute could take on the task for delivering an authoritative certificate for Muslim chaplains.

These conclusions do less complete the topic than they give more impulses for further, more theoretical reflections. There is no doubt that religious encounter supplies 'new' (old) religions in Europe (like Islam) with already proven institutional formats that can successfully be adapted to their own tradition. But differences do not disappear; new institutional forms continue maintaining some classical characteristics of Islam in the

1 This is why Michel Foucault traced the genealogy of modern governance back to the Christian pastoral power which consists of an individualizing truth-relationship between pastor and flock. 
United Kingdom. Similar phenomena can be observed in Germany, Austria or elsewhere.

Gilliat-Ray, Ali and Pattison empirically examine an institutional innovation in Islam in Europe. But their work also contains some theoretical implications for the study of religion. I would like to extract from the study two remarks that can help to continue the debate. The first one is still partially of empirical nature: Islamic chaplaincy as it has been empirically described appears to be very close to social work that now is to be flanked by classical Islamic ritual. Actually, we can here rather speak of an 'Islamic Deaconry' or 'Caritas' and not of typical pastoral care (Seelsorge).

But is this interchangeable use of social work and pastoral care simply a misunderstanding? Or do we rather have with a development that counts for the Christian pastoral care, too?

Here, I would like to point to the the fact that the line between social work and pastoral care is being blurred even within Christianity - thus, research from Germany shows that many pastors practically do more and more social work. The formation of Muslim chaplaincy takes place within this socio-cultural atmosphere. Is the Muslim chaplain practically a social worker with religious knowledge as an added qualification? It is an interesting question why the term chaplaincy could establish itself successfully.

My second remark is an appeal for more theoretical reflection. We may expect that particular innovations, such as Muslim chaplaincy, will have some repercussions in the general institutional form of a certain religion. In what form does the new religious role of Muslim chaplaincy affect the institutional field of Islam?

Depending on national regime of religion, the effects can vary significantly. In Germany and Austria, for example, institutionalisation of Islamic chaplaincy through recent introduction into university structures 
opens up new opportunities for Islamic umbrella associations to act as organisations that are similar to churches. Examining the differences between the UK on the one hand and (e.g.) Germany and Austria on the other hand can help to widen the practical, as well as, the theoretical scope of the debate.

\section{LEVENT TEZCAN}

CERES - Center for Religious Studies (Bochum) 